\title{
LEGAL RULES ON THE PURCHASE CONTRACT \\ UNDER THE CZECH NEW CIVIL CODE - \\ - SELECTED PROBLEMS \\ PRÁVNÍ ÚPRAVA KUPNÍ SMLOUVY \\ VE SVĚTLE NOVÉHO OBČANSKÉHO ZÁKONÍKU ČR - - VYBRANÉ PROBLÉMY
}

\author{
Martin JANKUீ - Karel MAREK*
}

\section{Introduction}

The adoption of the new Civil Code (thereinafter "NCC“) has brought a big breakthrough for the concept of the entire concept of ius privatorum of the Czech Republic. Previous to the adoption of the New Civil Code (thereinafter "NCC“) in 2012 the regulation of the commercial and non-commercial purchase contract was separated and split both in the Civil Code and Commercial Code in form of two complex sets of rules. Such duplicity was based on the dualism of the ius privatorum that reached to the legislation of both civil law and commercial law. This phenomenon had in Czech Republic its roots in the history of Austrian - Hungarian Monarchy and its Allgemeinies Buergegesetzbuch ${ }^{(1)}$. However, the Czech

JANKŮ, M. - KELBLOVÁ. H. - UHLÍŘOVÁ, M. - ZAPLETALOVÁ, D.: Nové občanské právo v kostce. C.H. Beck, 2014

\section{Abstract (EN)}

The goal of the present paper is to draw attention to some key rules and principles of the purchase contract. After the specification of this contract type we will deal in more details with the defective performance and the procedure of its complaint. As suggest the first assessment and reviews of the application of new legislation in its practical use and by the case law, in the achievement of the objective desired by the NCC - to increase the transparency of the procedure of complaints - the new legislation stacked in the middle of the way. The paper compares the impact of the new the previous and the current regulations, We will use the method of functional analysis as well as the method of legal formalistic comparison. It is obvious that the new rules respect the former régime of commercial contracts. The business sphere has undoubtedly welcomed this feature of the legal regime as the merchandisers are familiar with these rules. The second issue is, however, how this modification in the general regulation meets the expectations of the to provide sufficient legal certainty in the interpretation of contractual provisions and in the access to the protection of their interests by courts in the event of disputes.

\section{Keywords (EN)}

purchase contract, Liability for defects, warranty period, pre-emption right, trial purchase, purchase for probation period

\footnotetext{
* University of Finance and Administration, Prague, Czech Republic
}

Republic - taking the regulation in several other European states as a model - has decided to get rid of the dualism in ius privatorum.

\section{Material and Methods}

The goal of the present paper is to draw attention to some key rules and principles of the purchase contract. After the specification of this contract type we will deal in more details with the defective performance and the procedure of its complaint. As suggest the first assessment and reviews of the application of new legislation in its practical use and by the case law, in the achievement of the objective desired by the NCC to increase the transparency of the procedure of complaints - the new legislation stacked in the middle of the way. The paper compares the impact of the new, previous and current regulations. We will use the method of functional analysis as well as the method of legal formalistic comparison.

Cílem tohoto příspěvku je upozornit na některé významné instituty kupní smlouvy. Po vymezení tohoto smluvního typu se věnujeme otázkám vad a postupu při jejich uplatňování. První ohlasy a hodnocení aplikace nové úpravy v praxe a reakce judikatury naznačuji, že v dosažení vytčeného cíle - zvýšit transparentnost úpravy kupní smlouvy - zůstala rekodifikace na půli cesty. Z bližší analýzy a komparace je zřejmé, že právní úprava kupní smlouvy v NOZ vychází z úpravy, která byla provedena zrušeným obchodním zákoníkem. Příspěvek komparuje dopad nové úpravy za použití metody funkcionální analýzy, jakož i metody právně formalistické komparace. Jak je zřejmé, vychází právní úprava NOZ z úpravy, která byla provedena obchodním zákoníkem. To jistě uvítají osoby podnikatelské sféry. Tato úprava je jim totiž známá. Jinou otázkou ovšem je, jak tato změna obecné úpravy splňuje očekávání spotřebitelů na poskytnutí dostatečné právní jistoty při výkladu smluvních ustanovení a v prístupu k ochraně jejich zájmů soudy v prípadě prípadných sporů.

\section{Klî̌cová slova (CZ)}

kupní smlouva, odpovědnost za vady, záruční doba, předkupní právo, zkušební nákup, koupě na zkoušku 
It is obvious from the comparison made that the NCC rules are based on the rules contained in the former Commercial Code. Therefore, the entrepreneurs welcomed them. They may know them well from previous legislation. If we look to the Explanatory Report to the NCC, we may learn that the concept of the regulation is inspired by the Swiss regulation in that sense that it first contains general provisions common to all types of purchase. This is followed by the provisions on the purchase of tangible goods, the specific rules relating to the purchase of immovable property and provisions on supporting arrangements in purchase contracts. The general provisions follow definition of terms in the purchase contract, process of purchase price definition, as well as the specification of the fundamental obligations of the parties, taking specifically into account the issues connected with the performance and transition of risk of damage to goods. As regards the consequence of the provisions from the general to the specific arrangements we can only approve this innovation in the systematic approach. It is a new but materially and correct approach.

\section{Results and Discussion}

Characteristics of Purchase Contract as a Contract Type According to the General provisions of section 2079 NCC the seller undertakes by concluding the contract to deliver to the buyer the goods (assets) forming the subject of the purchase, and allow him to acquire the ownership right to it; and the buyer undertakes to take over the goods (assets) and pay the purchase price to the seller. If not otherwise provided by the contract or following the established practice, the seller and buyer are obliged to fulfill their obligations at the same time.

The subsequent provisions of $\S 2080$ rules, that the purchase price is deemed to be sufficiently explicit if it provides at least a method for its specification ex post. This can occur for example by agreeing the relevant costing formula.

If there are - during the contracting process - some defects with the goods about which the seller knows, he is obliged - according to section 2084 NCC - to draw attention of the buyer to these defects. The general provisions under the heading of Purchase end by the section 2084 and what follows are rules on Purchase of movable assets. The basic provision for purchase of movable assets of section 2085 specifies that the purchase of movables shall mean each purchase, the subject of which is not immovable property, as well as the purchase of a part of the immovable property if this part shall be acquired by the buyer after its separation as movable assets. As a purchase contract shall be always considered contract on the supply of consumer goods, which is necessary to be assembled or manufactured.

If the parties intend to conclude the purchase contract without determination of the purchase price, the price, for which is the same or comparable goods is usually sold at the time of conclusion of the contract and under similar terms and conditions is held for agreed.

We may predict, that the purchase contract - together contract for work - will conti nue to form two most commonly used contract types. The fundamental difference between the two types lies in the determination of the contracting types, whether it's about manufacturing of goods, or about the process of the manufacture. If the procedure makes the core of the contract, we will apply provisions on the contract for work, if - on the other side - the manufacture of goods constitutes the core then it depend fundamentally on who supplied the significant part of the goods. If the principal provided a substantial part, the arrangement is covered by the contract for work. It is capped on the contract. If a substantial part of the things supplied by the seller, we have to deal with the purchase contract.

If we compare the Czech legal rules from the former Commercial Code (making today the content of the NCC) with the text of the UN Convention on the international sale of goods (published under no. 160/1991 Coll.), we find that our Code aimed at a maximum compatibility the latter.

The reception of an internationally unified regulation (CISG) has to be evaluated positively. The law by this way is friendly for use by foreign persons.

The partial heading "Subject of purchase" introduces in the NCC the provisions of sections 2095 to 2098. The Explanatory Report notes that the subject of the purchase is movable (tangible) asset. The Report - even if otherwise consistently using the term "goods" - in the title of the heading and its opening provision is - for stylistic reasons - chosen the designation „subject of the purchase" instead of "goods as subject of the purchase". Materially, this provision is based on the content of the former Commercial Code.

The seller shall deliver to the buyer the subject of purchase in the quantity, quality and design. Should the quality and design not be agreed, the seller shall provide the supply in the quality and design suitable for the purpose following from the contract; otherwise is decisive the usual purpose of the goods.

\section{Rights from a Defective Performance of the Contract}

The provisions on the subject of purchase are followed by the provisions of sections 2099 to 2112 dealing with the legal consequences of defective performance under the heading Rights following defective performance of contract. The Explanatory Report notes to the latter that the draft originate in the former Commercial code as well. We miss here some provisions of general character that were transferred to the General part of Law of obligations. The changes therein consist in the enforced legal position of the buyer who received a defective performance. NCC has abandoned the criterion of removable and not-removable defects as the basic criterion for determining the rights of the buyer following the defects of the goods. It is replaced by the viewpoint of the intensity that the defective performance influenced the breach of the contract. If the defective performance constitutes an essential breach of the contract, the rights of the buyer shall be more extensive. What is essential, however, is that the rule on the prescription of rights from defects has been abandoned. The delayed reporting of defects (notification, complaint) does not lead to the extinction of the rights of buyer. Courts shall not take it into account ex officio and will refuse to grant the rights from defects to the buyer only in this case if an objection to this end will be raised by the seller. 
The goods is defective if it does not have the features set out in sections 2095 and 2096. Supply of alternative goods shall be considered as defective performance as well. As a defect of goods shall be considered also defects in the documents required for the use of goods. Supply of alternative goods is thus held for defect of the goods even if the goods supplied can be may be used for the purpose of the contract (the so-called performance „aliud”, for example, when - instead of corner valves - the seller supplies direct valves and bowed flanges).

If it follows from the bill of lading, proof of delivery of goods to or from the seller's declaration that the goods was delivered in smaller amount or only from a part, the NCC provisions on defects of the goods shall not apply to the goods not supplied.

The seller is liable for defects of the goods at the time when the risk of damage to goods passes to the buyer, even if the defect has shown only later. This shall be without prejudice to the obligations of the seller arising from the guarantee for the quality of the goods. The seller is also liable for any defect that occurs after this time, if it is caused by the breach of his obligations. Here it is appropriate to realise that the seller will have a broader scope of the liability when providing a warranty (see below) than solely due to implementation of the statutory provisions according to the Commercial Code.

In case of premature supply the seller may remove the defects till the deadline set for the delivery of the goods. By the exercise of his right he is not entitled to cause to the buyer unreasonable difficulties or expenses. The right of the buyer to damages shall remain unaffected. This applies, mutatis mutandis, to the defects of documents as well.

The rights of buyer following a defective performance shall be not affected when the defect arose as a consequence of the use of goods, which the buyer handed over to the seller. This does not apply if the seller proves that he has drawn attention of the buyer to the unsuitability of goods in due time and the buyer has insisted on its use, or when he can prove that he could not detect the unsuitability of the goods delivered even if when exercising due diligence. This regulation shall apply, mutatis mutandis, if the defect has been caused by an action of the seller in accordance with the proposals, samples or documents provided to him by the buyer ${ }^{(2)}$.

The buyer shall inspect goods, if able, as soon as possible after the transfer of risk of damage to goods and check its properties and quantity. Thereafter the buyer has no more rights following a defective performance, in of defects he had to recognize, when exercising usual care, already at the conclusion of the contract. The latter does not apply if the seller assures the buyer explicitly that the goods have no defects, or if he has masked the defect deceitfully.

If the contract provides for the dispatch of the goods by the seller, the inspection can be deferred until the goods arrives to the place of its destination. If the goods is directed during the transportation to another place of destination (for example to another place of business of the buyer) or redespatched by the buyer again (e.g. a subcontract of goods

(2) KAPITÁN, Z. Reklamace a následky porušení smlouvy podle Vídeňské úmluvy, Právní fórum, 2008, No. 8. for construction), without the buyer had the possibility - reasonably as to its nature - to inspect the goods and the seller knew, or ought to have known, at the time of conclusion of the contract of the possibility of such a change of destination or the re-dispatching, the inspection may be deferred until the goods has arrived to its new destination.

In the case of delivery of defective goods and an essential breach of the contract is the buyer entitled to choose alternatively one of the following rights

- to request the removal of the defects by the delivery of substitute goods for defective items, the delivery of missing goods and/or removal of legal defects,

- to request the removal of the defects by repairing the goods - should the defects be removable,

- to request an adequate discount on the purchase price or

- withdraw from the contract.

The buyer shall announce to the seller the option he chose when notifying the defects, or without undue delay after the latter. The choice made by the buyer can't be changed without the consent of the seller. This latter not apply, if the buyer asked for repair of defects, which will be shown as unrecoverable. If the seller does not remove the defects within a reasonable time or if he notifies he buyer that he will not remove the defects, the buyer may request an adequate discount from the purchase price instead of the removal of defects, or may withdraw from the contract. If the buyer has chosen his right timely, a procedure that applies is identical with the cases of non-essential breach of the contract (see below).

In the event of a non- essential breach of contract the options that may be chosen by the buyer are more restricted. The buyer may require either

- delivery of the missing goods and removal of other defects of the goods, or

- discount on the purchase price.

As long as the buyer does not exercise his right to a discount on the purchase price or withdraws from the contract, the seller may deliver the missing goods (parts thereof), or remove the legal defect. Other defects may the seller remove, according to his choice, by repairing or delivery of new goods. However, the choice met, shall not cause unreasonable costs to the buyer.

If the seller does not remove a defect or a defect in time things matter refuses to delete, the buyer may demand a discount on the purchase price or withdraw from the contract. The option chosen by the buyer can't be changed without the consent of the seller.

In practice, there are often cases when the buyer duly notifies the defects and at the same time pays the purchase price only from a part in the attempt to make pressure on the seller to remove the defect ${ }^{(3)}$. It is a procedure according to the law, provided that the delayed payment corresponds a potential discount from the purchase price. Before the removal of the defects is namely the buyer not obliged to pay the part of the

(3) JÄGER, M. - NAVRKAL, O. Oznámení o vadách podle obchodního zákoníku, Právní fórum, 2009, No. 11 
purchase price that corresponds to his claims for a discount should defects not been removed.

The buyer can't withdraw from the contract or to require delivery of new goods if he can't return the goods in the State as he received it. The latter will not apply if:

- the state of the goods changed as a result of an inspection in order to detect defects of the goods,

- the buyer used the goods even before the defects appeared,

- the buyer did not cause the impossibility to return goods in an unchanged state by his conduct or omission, or

- the buyer sold the goods even before the defects appeared, or he consumed and/or altered the goods during its use; if the latter occurred only from a part, the buyer returns to the seller what can be returned, and shall give pay to the seller up to the amount to that he could benefit from the use of goods.

According to section 2111 NCC, if the buyer has not notified defect in time, he shall loose the right to withdraw from the contract. Further, according to section 2112 paragraph 1, if the buyer has not notified the defect without undue delay after it could be detected by a timely inspection or sufficient care, the Courts will not grant him the rights from a defective performance. If there is a hidden defect, the same applies, if the defect has not been notified without undue delay after it could be discovered by the buyer with sufficient care, but not later than two years after the delivery of goods. The legal effects referred to in Section 2112 para. 1 shall be taken into consideration by courts only after an objection of the seller that the defect was not notified in time. However, the seller has no right to object, should the defect result from the fact the seller knew or had to know at the time of delivery of goods.

It can be only recommended to the buyer, when notifying defects of the goods, to choose the written form of the notification and to create appropriate evidence for possible additional procedure.

However, for any goods may be provided a quality guarantee. The Explanatory Report to NCC comments the rule that this concept of liability for defects is new for the general civil law. The former Czech Civil Code, No. 40/1964 Coll., based the regulation on an older concept of services, which originated in other social conditions in the 1960s and has been associated with a statutory guarantee. Such a concept is not familiar to the standard rules of civil law. Therefore, NCC returns to the rules (contained already in the Czech Commercial code) that separate the rights arising to the buyer from defective performance under the law, and rights arising to the buyer from the guarantee for quality. If the contracting parties agree on a warranty for quality, or the warranty for quality is provided by a unilateral declaration of the seller alone, the quality of the goods can be guaranteed in terms of time or as to the features of the goods. (Marek, Husták, 2014). The warranty for quality cannot, however, preclude the statutory provisions for the liability for defects of goods (this is of practical importance especially for hidden defects). The warranty for quality is ruled by the provisions of sections 2113 to 2117 NCC.
By the warranty for quality the seller undertakes to deliver goods, eligible for a certain period to be used for its usual purpose or that retain the usual properties. These effects are given even by placing the warranty period or shelf life of goods on the packaging or in advertising materials. The warranty for quality can be granted on an individual part of things.

According to our opinion, it is not excluded that the seller provides the warranty for quality only from a part (e.g. only against perforation by rusting bodywork) and the other parts underlie the statutory rules only. It is acceptable that on specific parts of the goods shall be provided a different warranty. For example, for cars a two-year warranty in general and a special warranty for six years on the bodywork six years ${ }^{(4)}$.

The commitment to warranty for quality may arise from the contract or from the seller's declaration, in particular in the form of warranty certificate. The effects of the acceptance of this commitment have also the statement on the warranty period or the time of shelf life of goods delivered that is marked on its packaging. If the contract or the warranty certificate contains a different warranty period, the latter shall apply.

If the contract and warranty statement contain different warranty periods, then the longest period shall apply. However, if the contracting parties arrange for a different warranty period than indicated on the packaging as the expiry date, the arrangement between the parties shall take precedence.

The warranty period begins by the handing over of goods to the buyer. If the goods was dispatched under the contract, it shall begin from the supply of goods to the place of destination. If the goods purchased shall be put into operation by other person than the seller, the warranty period begins only from the date of putting the goods into operation, provided that the buyer ordered the putting into operation no later than three weeks from the receipt of goods and provided properly and on time the necessary assistance for the performance of the services.

The buyer has no rights due to a warranty, if the defect occurred due to an external event after the passing of the risk of damage to goods. This does not apply if the defect was caused by the seller.

\section{Side Agreements in the Purchase Contract}

The last part of the paper is dedicated to side arrangements in the purchase contract that are regulated by the provisions of section 2132 to 2157 NCC. The Explanatory Report points out on the margin of this rules that the side arrangements in the purchase contract are of great practical importance, and for this reason the standard civil codes pay attention to their regulation. Both the previous Civil and Commercial codes regulated on a selective basis the reservation of title, the preemptive right, the right of repurchase and the trial purchase. These rules are used by the NCC, taken over to a broad extent, but the NCC, in conformity with standard European civil law, explicitly extends the side arrangements for reservation of the resale and reservation of better buyer, while

(4) BRYXOVÁ, V., Uplatnění nároků z odpovědnosti za vady prodané věci a jeho důsledky v majetkové sfére kupujicího, Právní rozhledy, 2009, No. 23. 
leaving the scope of side arrangements on a selective basis.

Significant changes occur in the modification of the arrangement for reservation of ownership rights and of the pre-emptive right.

The provisions on the reservation of ownership right prefer model of an extended reservation of ownership, which has chosen the former Commercial code in section 445. The latter allows to the contracting parties to condition the acquisition of ownership by the buyer by meeting other suspensive conditions than solely by the payment of the purchase price. It provides, at the same time, that a delay in payment with less than one tenth of the purchase price shall not entitle the seller to cancel the contract if the buyer pays the amount owed in the following instalment at the latest. The general rule on an essential and non-essential breach of contract is applied in a concrete shape and the risk of unnecessary litigations is moved aside ${ }^{(5)}$. Given the dispositive nature of the arrangement, however, an arrangement of partiers to the contrary is not excluded. With due regard to the construction employed by the Italian civil law, the NCC stipulates that the seller cannot claim his reserved ownership right as against creditors of the buyer, unless he proves in a credible way the possession of the reservation of ownership and when it was agreed upon.

Provisions on the right of pre-emption reflects the practical experience with the rules existing before. These lead, due to imperfectness therein, different interpretations and overall legal uncertainty. The new rules are still based on the previous ones but also pay to a large extent due regard to the sophisticated German legislation (sections 463 to 473 BGB).

As regards the reservation of title, if the seller reserves the right of ownership to goods sold, it is considered that the buyer becomes the owner only after the complete payment of the purchase price. The risk of damage to goods, however, passes to the buyer already upon the takeover of goods.

If the acquisition of the ownership right by the buyer is subject to payment of the purchase price in instalments, the seller shall not use the delay in payment not exceeding onetenth of the purchase price for his right to withdraw from the contract and demand the return of goods, shall the buyer pay the instalment no later than at the time of the next due instalment and together with it $^{(6)}$.

The reservation of ownership right has effect towards creditors of the buyer only if the arrangement has been made in the form of public documents, or if it is in a written form with signatures of the parties officially verified (the date of the official verification of the signature decides). However, if the reservation of ownership right regards the property recorded in a public list, it shall have effects against third parties only if recorded in this list as well.

Another side arrangement ruled by the NCC is the reservation of repurchase. From the arrangement of the reservation of the reverse purchase the obligation shall arise to transfer the goods to the buyer on his request against payment of the purchase price. The buyer shall return the goods to the seller

(5) LAVICKÝ, P. a kol.: Občanský zákoník I. Obecná část (\$ 1 654). Commentary, 1st ed., C. H. Beck, Praha 2014.

(6) TICHÝ, L: Komentář k § 2095 Občanského zákoníku, ASPI. Wolters Kluwer, 2013. in an unworsened state and the seller returns to the buyer the purchase price. By that the potential the rewards and/or fruits from the goods shall be compensated.

Reservation of reverse purchase shall oblige heirs and the right to reverse purchase can be assigned to a third person only if explicitly agreed upon.

If the time limit for the seller's right to request the return of goods has not been agreed, a three-year period as for tangible assets and ten-year period of non-tangible assets shall be considered for agreed upon.

The provisions of section 2136 then rules issues concerning the costs spent in respect to the goods by the buyer. If the buyer spent costs on goods in order to improve it, or extraordinary expense for its conservation, he shall be entitled to identical compensation as to a possessor bonae fidei ${ }^{(7)}$. However, if the returning of goods is rendered unfeasible or the value of the goods depreciates for reasons for which the buyer is responsible, he shall be obliged to compensate the seller for the damage.

If the reservation of reverse purchase has been agreed with respect to properties recorded in a public list, the any right representing a burden to such properties can be agreed only with approval of the person registered with the right of reverse purchase in such a recorded.

The new provisions rule also for reservation of reverse sale, where - under the section 2139 NCC, the provisions for reverse purchase shall apply, mutatis mutandis, also to the arrangement whereby the buyers shall reserve the right to sell the goods back to the seller.

The following sections of the NCC - 2140 to 2149 NCC contain the rules for the pre-emptive right. In the paper we will discuss only the introductory provision and for further details we refer to the quoted statutory provisions of the NCC. If the seller agrees with the buyer to arrange for pre-emptive right then the buyer shall be obliged to offer the goods back to the seller in the case he should intend to sell the goods to a third person.

Pre-emptive right can be a special arrangement extended to other methods of disposal. You can also make pre-emptive right outside the link with the purchase contract.

The provisions of section 2150 NCC rule for a purchase with probation period. According to the rules it is agreed that the buyer, who purchased the goods with probation period, shall buy the goods subject to the condition of approval within the probation period. In absence of explicit agreement on the length of the probation period, a three-day period for tangible assets and one-year period for intangible ones, as from the conclusion of the contract, is considered for agreed. However, if it follows from the negotiations on the contract, that the goods is to be inspected or tested after the delivery, the probation period runs from the delivery date.

If the buyer has not taken over the goods, the above condition has the character of a suspensive condition, and the latter shall be held for spoiled should the buyer not inform the seller within the probation period that he has approved the goods. If the buyer has taken over the goods, it shall have

(7) TICHÝ, L. - PIPKOVÁ, P. - J. BALARIN, J.: Kupní smlouva v novém občanském zákoníku, 1. Ed., C. H. Beck, Praha 2014. 
the character of a cancellation condition and the goods is considered to be approved if not refused in writing within the probation period. The buyer has not the right to reject the goods if it can't be returned in the state in which it has been taken over. The changes caused by trying of the goods shall be not considered.

In addition to the purchase for probation period arrangements on a purchase after the probation period, purchase in dependence on a probation period, purchase with reservation $\mathrm{n}$ of the exam can be arranged after the test purchase, buy, purchase subject to exchange, right of option and other may be agreed upon. The freedom of contract can be employed in these cases to full amount.

However, it is also possible to agree on the reservation of a better buyer that the stipulated by the provisions of section 2152 and 2153. By the conclusion of the purchase contract with reservation of a better buyer the seller shall give preference to a better buyers, subject to his application purchase within a specified period of time. This period is set for the sale of tangible assets for three days and for intangible assets for one year after the conclusion of the contract. Whether the new buyer is a better one, shall be decided by the seller. $\mathrm{He}$ is entitled to give preference to a new buyer, even if the previous one has offered a higher price. Similarly to the trial purchase it shall be assessed, in which cases the reservation of a better buyer has character of a suspensive condition or of a cancellation condition.

As regards the pricing clause, the NCC in the sections 2156 2154 takes over (with minor changes) the legal rules of the Commercial Code ${ }^{(8)}$. The pricing clause can be agreed upon in various ways (as we have already pointed out in the text about the negotiation on the purchase price). Its aim is to prevent the adverse effects of price increases in fixed-price subcontracts in the case of otherwise fixed price of the final goods. If the parties agree in determining the price that its amount is to be subsequently modified with regard to the production costs, and shall not specify the decisive components of production costs therefor, then the purchase price changes in proportion to the price changes of the main raw used for the manufacture of the goods under sale (general price clause)

Unless the parties shall agree in the contract what that time is decisive for the assessment of the price changes, due regard shall be taken to the prices at the time of conclusion of the contract and at the time when the seller had to deliver the goods. If the delivery of goods takes place during a certain time limit, the time of the actual timely performance shall be decisive, otherwise the end of this time limit. If the seller is in delay with the delivery of the goods, and at the time of actual delivery are the prices for main components for the production cost lower than the prices in the time specified above, these lower prices shall be taken into account.

The rights and obligations of the parties from the pricing

(8) In the Czech Republic we can take advantage of contractual arrangements, typical differently for contractual obligations in international trade, in accordance with the principle of fair trade. You may for example. I arrange currency conversion, if the price in the contract listed in CZK and agreed that, for example, has to pay in EUROS or another currency. clause shall cease to exist if the entitled contracting party shall not make use of its rights by the other party without undue delay after the delivery of goods. By passing of the time limit "without unreasonable delay" the rights cease to exist, as this period is defined as prescription period

Other reservations and conditions can be arranged in the purchase contract as well. For instance, even between contacting parties with their established seat a currency clause may be agreed upon (that was ruled also by the Part III of the Commercial Code). According to our opinion, in particular machinery and electrical engineering goods gradually tend to recall a assembly kit when using components manufactured in different countries of the world. In such a case the price of the domestic deliveries may be dependent on the exchange rate of the respective currencies. If the contract provides that the price or other pecuniary obligation is to be understood as given by a specific exchange rate of the currency, in which the obligation is to be fulfilled (ensuring currency), to some other currency, the debtor shall be obliged, if after conclusion of the contract the exchange rate of both currencies changes, to pay the amount of the price reduced or increased so that the amount in the ensuring currency remains unchanged.

\section{Summary}

The legal regulation of the purchase of goods is the most extensive of all contract types contained in the NCC. However, it is principally of dispositive character. Even if the relative extensiveness of NCC can't include all issues and provisions that would be suitable to be agreed upon, so as it can 't take into account all specifics of the different subjects of the contract (e.g. construction materials, alloy steels, castings, hardware components etc.). Therefore the contracting parties, when closing a purchase contract, have to pay due attention to the contracting procedure.

As regards the rules on the rights following defective performance, these should - according to the aims of the legislator - bring a higher transparency and simpler application of these rights. It is, however, a paradox, that the merging of the regulations of former Commercial Code and Civil Code to the NCC has lead rather to the creation of higher legal uncertainty as to which interpretation of the rules should be given preference. One has to admit that even after a detailed study of the NCC rules on how to bring of complaints it is not easy to say what are the rights - in particular in relation to the consumer - that are guaranteed by the law. We may conclude our paper by the statement that, from the perspective of the consumer, the consumers may be under the NCC are curtailed in their existing rights. Entrepreneurs, or "predominant parties" to the contract, the NCC, by contrast, offers the opportunity to take advantage of legal gaps to their favour, for example, by not recognising the complaints for defect in goods to consumers to such extent as under the former legal regulation. The clarification of this probable interpretation of the NCC rules requires amendments to the existing rules by the legislator in short terms, or at least a clarification of the situation by the case-law of the higher courts.

As regards the new extensive rules have brought larger flex- 
ibility for the contraction parties intending to take account to various conditions and circumstances of the purchase. The new regulation can be an inspiration for the contractors in the Slovak Republic to amend these arrangements to their contracts, even when applicable under the Slovak legislation. The dispositive character thereof can't, namely, cause any effects that would be contra legem.

\section{References}

1. BRYXOVÁ, V., Uplatňování nároků z odpovědnosti za vady při prodeji zboží v obchodě, Právní rádce, 2009, No. 7.

2. BRYXOVÁ, V., Uplatnění nároků z odpovědnosti za vady prodané věci a jeho důsledky v majetkové sféře kupujícího, Právní rozhledy, 2009, No. 23.

3. JÄGER, M. - NAVRKAL, O. Oznámení o vadách podle obchodního zákoníku, Právní fórum, 2009, No. 11.

4. JANKU゚, M. - KELBLOVÁ. H. - UHLÍŘOVÁ, M. - ZAPLETALOVÁ, D.: Nové občanské právo v kostce. C.H. Beck, 2014.
5. KAPITÁN, Z. Reklamace a následky porušení smlouvy podle Vídeňské úmluvy, Právní fórum, 2008, No. 8.

6. LAVICKÝ, P. a kol.: Občanský zákoník I. Obecná část (§ 1 654). Commentary, 1st ed., C. H. Beck, Praha 2014.

7. MAREK, K. - HUSTÁK, Z: Koupě obchodního závodu - k některým předpokladům uplatnění práv $z$ vadného plnění. 2014. Online available on http://www.pravniprostor.cz/clanky/ obchodni-pravo/koupe-obchodniho-zavodu-k-nekterympredpokladum-uplatneni-prav-z-vadneho-plneni v

8. TICHÝ, L: Komentáŕ k § 2095 Občanského zákoníku, ASPI. Wolters Kluwer, 2013.

9. TICHÝ, L. - PIPKOVÁ, P. J. - BALARIN, J.: Kupní smlouva v novém občanském zákoníku, 1. Ed., C. H. Beck, Praha 2014.

\section{Contact address/ Kontaktná adresa}

Doc. JUDr. Martin Janki̊

VŠFS, Estonská 500/3, 10100 Praha 10, email: jankum@mendelu.cz prof. JUDr. Karel Marek, CSc.

VŠFS, Estonská 500/3, 10100 Praha 10 